\title{
Joint-Ownership on Agricultural Land: A Case Study on Muamalah Contracts and The Shariah Model
}

Jasni Sulong, Mohd Marbawi Taha

To Link this Article: http://dx.doi.org/10.6007/IJARBSS/v11-i11/11288

DOI:10.6007/IJARBSS/v11-i11/11288

Received: 10 September 2021, Revised: 12 October 2021, Accepted: 24 October 2021

Published Online: 17 November 2021

In-Text Citation: (Sulong \& Taha, 2021)

To Cite this Article: Sulong, J., \& Taha, M. M. (2021). Joint-Ownership on Agricultural Land: A Case Study on Muamalah Contracts and The Shariah Model. International Journal of Academic Research in Business and Social Sciences, 11(11), 1293-1306.

\section{Copyright: (c) 2021 The Author(s)}

Published by Human Resource Management Academic Research Society (www.hrmars.com)

This article is published under the Creative Commons Attribution (CC BY 4.0) license. Anyone may reproduce, distribute, translate and create derivative works of this article (for both commercial and non-commercial purposes), subject to full attribution to the original publication and authors. The full terms of this license may be seen at: http://creativecommons.org/licences/by/4.0/legalcode

Vol. 11, No. 11, 2021, Pg. $1293-1306$

Full Terms \& Conditions of access and use can be found at http://hrmars.com/index.php/pages/detail/publication-ethics 


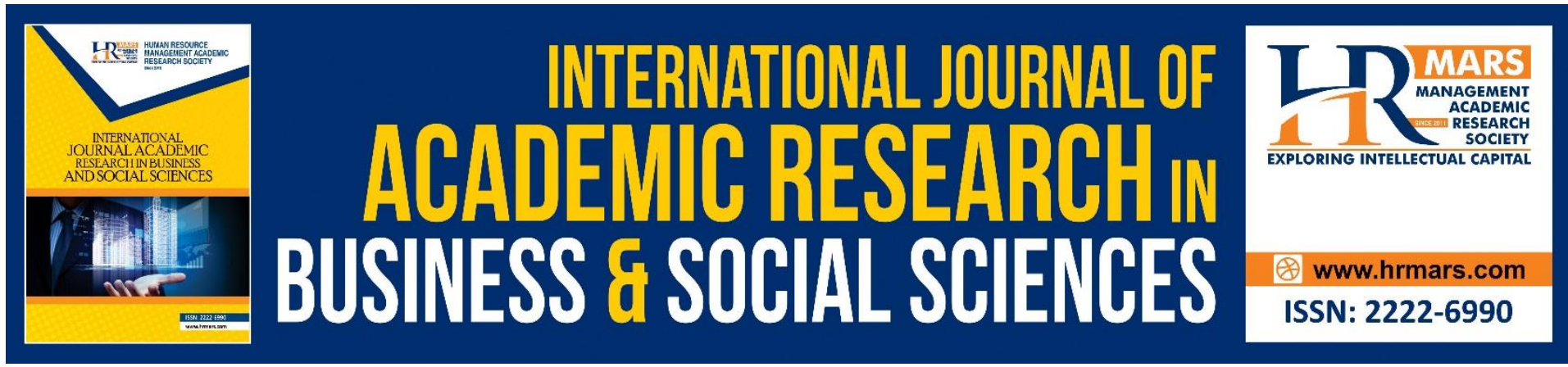

\title{
Joint-Ownership on Agricultural Land: A Case Study on Muamalah Contracts and The Shariah Model
}

\author{
Jasni Sulong \\ School of Humanities, Universiti Sains Malaysia \\ Email: jasni@usm.my \\ Mohd Marbawi Taha \\ Academy of Contemporary Islamic Studies, Universiti Teknologi MARA \\ Email: mohdmarbawi620@uitm.edu.my
}

\begin{abstract}
Joint ownership is sharing ownership on a particular property either between two or more co-owners. As co-owners, they have equal rights on the property, primarily agricultural land, either to benefit or dispose of the land. However, there are some problems in the governance of joint ownership of agricultural land. Among the issues are that some owners do not know which side they own, the responsibility to pay rent, and profit distribution when authorities are going to take part of the land, especially when there is a conflict. This study aims to resolve the problems and underline a shariah-based model to handle and manage the joint ownership of agricultural land. The methodology used in this study is a mixed methodology involving library and field research. All discourses related to this matter will be pondered with the views of Islamic scholars and recent practitioners. Thus, all analyses and recommendations are a solution between theory and practice. The implications of this study will reveal the alternative way to resolve problems that occur in joint ownership of agricultural land, especially that impact a social, developmental, and economic point of view. In the finding, this study will propose a shariah-based model that can help address these problems. Hopefully, this study can positively impact the joint owners in terms of their welfare and benefit the economic value of the estate. Ultimately, cooperation between joint-owners is essential to ensure that all planning and management of agricultural properties can continue. The success of the collaboration is not only benefits co-owners future but on the economic value of the land-site as the capital.
\end{abstract}

Keywords: Co-Ownership, Waqf, Heirs, Property, Inheritance

\section{Introduction}

Jointly owned land means land owned by two or more persons collectively, to which each owner is entitled to the entire land. Under the Islamic partnership, joint ownership can be found in a mixed property (mal al-musha). In the Malaysia National Land Code 1965, joint ownership land is precisely provided under Sections 342 and 343. Section 342(1) explains that 
joint ownership means holding land owned by two or more persons or bodies in undivided parts. The undivided parts have attracted this study to be done as it invites various problems, especially for social and economic aspects. Therefore, this study aims to suggest recommendations on the difficulties and a model to be tailed. It is hoped that the results of this study will bring benefits to the authorities and landowners, especially in safeguarding the welfare of the joint owners towards the productivity of the agricultural land.

\section{Problem Statements}

The main issue in joint ownership is the limited self-determination of the joint owners to manage and deal with their land. Even though every joint owner can enjoy any part of the land, the enjoyment is minimal. They need to deliberate and obtain a mutual agreement in matters relating to physical building or planting. The issue is that it is unknown which joint owners specifically own part of the land. Even though Section 343(1)(b) of Malaysia National Land Code has provided that, ".... so long as their joint ownership continues, shall each be entitled to the ownership and enjoyment of the whole", the provision is general and not explicitly stating the particular part. In elaborating this general clause, Rashid (1971) has explained that joint owners actually hold the land in the form of "undivided shares" which is all of them are concurrently owners of the land, and no one is entitled to a specific part as a sole owner to the exclusion of the other or others.

For the undivided shares, a problem often occurs when the joint owners unofficially divide the land into several parts by making a boundary such as fences, trees or walls (Aziz, n.d.). The partition or borders created is illegal and not acknowledged under the Land Code (Buang, 2000). For instance, when a State Authority take part of the joint ownership land, the compensation will be distribute to all joint owners. According to Section 343(1)(b), the State Authority must pay compensation to all owners according to their respective share rates regardless of the division that was done physically on the land. Therefore, even if the government does not take the part that one of the joint owners has done a physical building on the site, he is still entitled to compensation. This practice in calculating payment on land acquisition often causes disputes among owners. According to the previous Minister of Natural Resources and Environment, Khalid (2008) explained that the problem occurred widely throughout the country due to the land acquisition on the part of joint ownership land.

Another problem is the difficulty of reaching an agreement between joint owners for subdivisions, changing land use, etc. The conflict occurs as every party has equal rights on the land, which in some cases ended in court due to failure to obtain mutual consent among them. For instance, in the case of Ku Yan Bte Ku Abdullah v. Ku Idris Bin Ku Ahmad \& Others (1991) and Aisyah binti Mohd Saman and three others v. Kalsom binti Mohamad Nor (2001), the plaintiffs took the cases to court, as a result of their disagreement in making subdivision. Despite the consent problem, the conflict also arises in paying the land tax. Some joint owners did not participate in sharing the cost, resulting in tax arrears for years. The intolerance attitude and irresponsible will cause the land to be confiscated, as provided in section 100 of the National Land Code. In that situation, all owners will bear the loss (Suman, 2012).

Obviously, cooperation and understanding between joint owners are essential. When there are disagreements between owners, the land cannot be utilized, which makes the land frozen and uneconomical. Eventually, it will spark a bad relationship between the owners. To add salt, most joint owners consist of immediate family members such as siblings and relatives. Thus, their arguments left a more severe effect as it will destroy family ties and longstanding friendships. The disputed land continues to become idle and non-productive. 
Nothing can be done on the land as joint owners do not have an equal mind. Therefore, many abandoned lands were found in villages or cities, where no buildings were built as well as no crops or livestock activities were cultivated (Suman, 2012).

The lack of understanding in managing jointly owned property becomes complicated as more and more owners share it. If one of the joint owners dies, it will increase sharers through inheritance. According to Khalid (2008), idle land accelerates when the land has too many co-sharers until the value becomes unusable. A simple case on the joint ownership issue is ownership in Kampong Baru in Kuala Lumpur. It was reported that a lot of land in Kampong Baru was owned by 141 joint owners. The land area is about 809,345 square meters, with the smallest part being only $7 / 424320$, representing an area of 0.01335 square meters. If one square meter is worth RM1000, then the value of the smallest part is only RM13.35. This rate of possession is of no value and unusable, especially for trading, leasing, financing, etc. (Othman, 2009).

In sum, joint ownership on a piece of land which involves many co-sharers is a problem that must be resolved soon. The more owners who share the land, the more problems there will be. Based on the data obtained, the issue of idle land in the country is quite severe. Records from the Department of Agriculture Malaysia of 2020 have stated that about 97,275.19 hectares of land in Malaysia are uncultivated and become idle, and one of the causes is joint ownership (Aziz, 2009).

Therefore, based on the problems that have been discussed, this article aims to identify the position of joint ownership in Islam and resolve the issues of joint ownership. The study will investigate this joint ownership from various contracts and types of ownership. The study will discuss the position of the joint ownership based on the shariah standards that need to be complied with. In addition, the study also tries to propose an appropriate model to be implemented either at the level of the individual or the authorities involved.

\section{The Concept of Joint Ownership in Islam}

Joint ownership is permissible, and it happens in Islam in a few muamalah contracts. Such ownership occurs either as a result of inheritance, partnership (syarikah), or bequeathed by someone in sharing mode or obtaining it through a gift (Asni \& Sulong, 2021). It also appears among recipients of waqf benefit, especially under family waqf. Such method of ownership led to two forms of possession i.e. ownership based on specific division such as through faraid, or partnership, or ownership based on general division such as through bequest and waqf. This situation affects different rights and functions in managing the asset.

Inheritance through faraid is a natural method of transferring property in Islam. This transfer takes place after the death of the property owner and the life of the heir, with the condition that there is property left for the heir. The ownership of the property by these heirs is based on the percentage set by Islam. The heirs will share on the property if their number is large and the property is limited. The heirs' share of the estate is based on a portion that was stated by religion, which is either one -eighth, one-sixth, one -quarter, one -third, one half, or two-thirds (Jaburi \& Hamish, 2007). Therefore under faraid, even if the heirs share ownership over a property, the joint ownership is based on a certain portion according to their qualifications. The larger share owned by owners shows that the more rights they own.

Joint ownership also occurs in a property owned under partnership (syarikah). Two or more people who have shared purchasing a company, land, or house will make them coowners. If their capital is equal, then their partnership rights are equivalent (Nawawi, n.d.). So conversely, if their share is different, then their rights depend on how much percentage 
was contributed. If their partnership is mixed (musya), they have equal rights without knowing which part of the property is their right (Zuhayli, 2015). In this case, mutual agreement in performing a transaction is essential.

Acceptance of a will or bequest can also be resulting joint ownership. This is because the recipient cannot determine the form and method of the will he receives, which is entirely subject to the property owner's will (Jaburi \& Hamish, 2007). Thus, a group of testators who are given a joint share in a property after the testator's death will cause them to own it in partnership. Each co-owner's share depends on the testator's determination in a specific portion or in general (musya). After all, the management of will's property is dependent on mutual agreement.

The same goes for the property to the recipient more than one individual, during lifetime. If the owner gives it so that the recipient owns a property, then the form of transfer of the property conveyed is in partnership. Therefore, the joint owners need to manage the property wisely so that the benefits of the property can be enjoyed equally. Such giving does not only happen in the form of gifts, but also happens in the form of waqf. A person who endows his property to the public or family members, will cause the benefits to be shared by many recipients. Although ownership in waqf property is not like other property, sharing benefits between them is equal and equivalent (Kahf, 2011). Their rights on waqf assets are like co-owners who have the right to enjoy it at any time and in any form.

Apparently, all of the above transactions under the Islamic transactions have proven that joint ownership may happen, and some of it has already taken place through inheritance, partnership, will, gift, and waqf (Asni \& Sulong, 2021). The discussions have shown that joint ownership is a common result that occurs from a contract. Thus, it is not an issue but what needs to be examined is the individual's planning and their management in anticipation of this. Each co-owner has to manage and plan the joint ownership in a very good manner so that each party can benefit from the rights and avoid disputes. Thus, this will prevent the property from becoming abandoned and uneconomical.

\section{The Management of Joint Ownership on Muamalah Contracts}

The previous discussion showed that many contracts could result in joint ownership among Muslims. Every contract has its own character, and therefore each joint owner needs to understand their rights and limitations over the shared property. They have to find ways to enjoy the benefits so that they can share the profits with other owners fully. In this study, the discussion will focus on joint ownership that commonly takes place in one Muslim family.

The discussion will refer to the second and third generation as most of the effects of joint-ownership are derived from transactions or contracts that the first owner committed, such as after inheritance, wills, endowments, gifts, sales, etc. Three forms of transactions led to joint ownership in Malaysia nowadays, likely family waqf, FELDA inheritance, Islamic inheritance, and the establishment of a family company.

\section{Joint Beneficiaries in Family Waqf}

The joint beneficiaries in the family waqf give the right to take equitable benefits as they are co-owners on the assets. In Arabic, family waqf is a term retrieved from the words waqf ahli, where ahli refers to family (Nawawi, n. d.). Thus, mentioning "family" after the word of waqf describes that they are the receivers of the waqf's profits. They are entitled to benefit the waqf collectively as they are a joint owner of the property. Family members will benefit from the said waqf, including children, grandchildren, spouse or relatives of the waqf creator (Zaki, 
1995; Sulong, 2019). As joint-owners, the beneficiaries of the waqfs will enjoy the benefit where no one can stop them from enjoying the advantages legally.

The management in family waqf properties sometime faces problems when the entrusted manager (mutawalli) fails to take good care of these properties. In this case, family waqf needs a trustworthy manager so that the asset will remain productive as well as the benefit. If the waqf asset left unmanaged, then each heir will take off hands and does not want to take responsibility for ensuring the sustainability of the waqf property, whether it is a building or plant. This situation has led to some of the waqf properties not being utilized $(34.6 \%)$, detrimental to heirs, and caused the waqf property to be uneconomical (Suhaimi, 2018). The attitude of joint beneficiaries who give up and wait for the rest of the heirs to take action, then the productivity of a family waqf will be damaged and does not last long.

Therefore, each waqf beneficiary has to make bold action and innovation and work hand in hand so that the waqf asset will become productive and progressive. As a result, it will provide a valuable return to the joint beneficiaries. This return does not in the form of continuous reward to the waqf creator only but also provides multiplied benefit to the descendants and the so-called joint beneficiaries. For instance, the productivity of family waqf in Singapore (Karim, 2000) that was bestowed by Syed Syed Omar bin Ali Al-Junied (Said, 1977) and has built a few endowments such as Omar Mosque, Al-Kaff Garden, and arcade buildings (Talib, 1997). Most of these waqf lands are in perfect locations (Hashim \& Omar, 2007), which has generated well-paid revenues. The profit goes to their offspring's educational trust and also for servicing people by establishing a free clinic. Thus, mutawalli needs to find solutions and alternatives to ensure the goal of waqf initiator is preserved. Based on Singaporean achievement, the planning and cooperation of the heirs as the joint beneficiary of the waqf property is essential to ensure that the assets are sustainable and the benefits remain for the second generations, and so on.

Nowadays, family waqf property exists in various forms such as cemeteries, pondok, madrasah, farms, buildings (shops, shophouses, residences), etc. Some of those assets provide benefits in the form of services, and some contribute to income and finances. For example, recipients of family waqf will benefit from these advantages in form of rental revenue, cash, share, takaful, and other free services such as hemodialysis and medical facilities (Mahamood, 2007). All profits and benefits are the outcome of innovation in family waqf. In this case, the successful implementation of previous family waqf should be taken as an example so that the benefits of family waqf initiation and goal can be achieved (Saduman \& Aysun, 2009).

\section{Joint ownership on FELDA's Agricultural Land}

FELDA has a unique succession land law to the second generation, which is the land only transferred to two nominees after the demised of the first owner. Section 7 of the Land Group Settlement Areas Act 1960 (Act 530) prohibits the names of heirs from being registered in the land title except for two nominees. However, the rights of the other heirs are not denied by the Act. The provision only works from a technical point of view, while all legal heirs are entitled to it from a religious point of view. In other words, each heir has their right in terms of faraid law, and the two nominees will act as administrators to other heirs. The administrators must seek the opinions and views of other heirs in managing the agricultural land (plantation). At the same time, they are responsible for distributing the profit to the heirs according to faraid law or as agreed by the heirs (Wan Harun, 2012). According to Nor 
Muhammad and Mat Hussain (2014), this kind of succession is based on government policy to sustain the land and guarantee plantation value.

Therefore, the two nominees will become trustees and responsible to other joint owners because the latter also carries the same weight of ownership. Their power over the property is limited even if their name is listed as the owner. Under FELDA regulation and with the recognition of mufti, all legal heirs are held joint ownership on the home site and plantation. This kind of ownership happens for FELDA second and third generations and they collectively have their rights. At the same time, the existing regulation for settlers who cannot sell or lease the FELDA home site and plantation has remained, and they shall manage the assets as required by the management of the FELDA. Thus, settlers must abide by all the rules set by the FELDA, including in the form of joint ownership (Group Settlement Areas Act, 1960).

In this case, FELDA's land is similar to waqf khas where the benefit of the property is focusing only on the family benefits. In order to benefit the property, which involves 10 acres of plantations, the remaining heirs who continue their father's work as a settler are need to be appointed as an administrator to represent the rest. The administrator will execute all physical works on sites, while the other heirs will be the planners or capital initiators to develop the property. At the same time, they can work together to facilitate the management in developing the land and increasing revenue. In order to ensure the management of the asset in an orderly manner, cooperation of all heirs is essential in providing assistance, capital sharing, and moral support (Nor Muhammad and Mat Hussain, 2014). Otherwise, it will add complexity in cultivating 10 acres of farmland just of two but at the same time have to sustain the revenue in high feat (Ramli and Ahmad, 2014).

Therefore, every heir must collaborate in managing the plantation site with cleaning, planting, fertilizing, and harvesting activities so that the results obtained are as expected. In this case, the joint owners will share an equal profit. Even though the land is stated for two nominees, the consensus among the heirs regarding farm management, technologies installed, and capital sharing is on a collective basis (Mohamad, 2007). Since joint ownership in FELDA land only involves nuclear families, then its management is more straightforward than other forms of partnership. Siblings need to work together, hand in hand, to ensure that their father's legacy continues and is sustainable for future generations. Any constraints should be faced openly by avoiding disputes that would only be to their detriment (Awang, 1994; Mohamad, 2007).

In a big family, sometimes not all members or siblings are interested in managing the farm. In this case, the uninterested heir can withhold his share and sell it to the interested heirs. This step of action will shrink the number of co-owners and increase profit sharing. At the same time, farm management will be easier to administer as the number of views is reduced (Muhammad and Hussain, 2014). Hence, the property becomes well-managed, and on the other side, the uninterested heirs will get a sum of capital to start another business, and buy something planned. By doing this, the family property has become more productive and meets the goal of FELDA when initiating the program at an earlier time (Ahmad, 2017).

At the same time, the method of joint ownership in FELDA is in line with the Islamic religious authorities' view, that is, based on public benefit or maslahah. Based on the 38th Muzakarah of the Fatwa Committee of the National Council for Islamic Religious Affairs Malaysia, which convened on 21 June 1995, the management of FELDA Land property must be handle on an agreement basis among legal heirs. All heirs must agree to appoint one of them as a representative to manage the estate. If there is no agreement, the deceased's property shall be sold, given priority to the heirs as the buyer. The profits are divided among 
the heirs, according to faraid. Surplus property is handed over to the Baitulmal if no heirs are entitled to inherit. By doing this, the goal in initiating the FELDA will be achieved wholly, and each heir entitled to their shares equally.

\section{Joint-Ownership on Inheritance Land}

The ownership transfer through inheritance to children and other heirs results in the occurrence of joint ownership. This kind of ownership happens when many heirs inherit on a limited property. The automatic transfer occurs upon the owner's death, based on faraid law that underlining legal recipients and their authorized portions. The lawful rights have been provided in Surah al-Nisa', verses 11, 12, and 176. In the verses, Islamic law only states each share of the heirs without distinguishing the type of physical distribution and type of property. According to Wan Ali \& Ahmad (2014), the universal rule gives flexibility to the heirs. It avoids rigidity in the distribution of property among heirs. Therefore in joint ownership possession, each heir has liberty either to maintain the ownership or dispose of it to co-owners by selling or gifting or, etceteras. By keeping the property, the owners have to endure managing the property productivily, so that it will become a vital source for their living and for the good of future generations of families (Ahmad \& Ibrahim, 2006).

Since inheritance is a kind of involuntary contract, every legal heir is not compulsory to receive the portion. As the handover process inevitably took place after the demised of the owner, the entitled heir has the right to refuse the share. In the case of joint ownership, some heirs can let it go to other co-owners for free or cash. In faraid, the deal is known as takharruj, where the co-sharers can offer any of them to own his portion voluntarily. Ibn Manzur (1990) identified takharruj as a rejection of particular heirs over his inheritance and hands over that share to other heirs. Hasari (1992) describes al-takharuj as the reconciliation of certain heirs by partially withdrawing from taking his inheritance. This meaning is in line with the description stated by Shalabi (1978), al-Jaburi and Hamish (2007). Thus in joint ownership, coowners have the right to dispose his share to others but have to reach a consensus in managing the disposal of the whole estate or make an investment (Ali \& Ahmad, 2013; Ali, 2016; Jamalludin, 2016).

This consensual agreement is essential in managing co-ownership property because it makes the administration easy and orderly. According to Ahmad (2017), the practice of consensus (muafakat) in the joint property leads to a similar meaning: tolerance among the heirs (Ahmad \& Laluddin, 2010). This consent was also needed for inheritance trial and this stand is in line with the meaning of Surah al-Nisa', verse 29 which means, "O you who have believed, do not consume one another's wealth unjustly but only (in lawful) business by mutual consent".

As long as there is mutual consent, where each party engages with a peaceful settlement or consensus, formal jurisdictive is only a formality. Islam acknowledges the arrangement, and it happens widely in societies globally (Ahmad, 2017; Cohen 1978). In this case, the study found two forms of negotiations, either officially by attending a court session or unofficially by engaging in a mutual understanding. One's own family can evaluate the unofficial engagement or competent people such as priests, village heads, and kadi. (Ahmad, 2017).

Therefore, a method of discussion among joint owners is essential in getting a solution over the shared property. Islam has a process of sulh (peace resolution) in dealing with conflicts and satisfying every parties' needs and rights. The best goal to achieve is by having a consensus so that each joint owner has peace of mind according to the management of the 
shared assets (Ibn Manzur, 1990). According to Isfahani (1961), sulh is the best mechanism in ending disputes between human beings. Ibn Humam (n.d.) and Kasani (1986) have mentioned that any agreement that undergoes sulh becomes a contract and binding every one of them. Similarly, Nawawi (n.d.) opined that the method of sulh resolves disputes and avoids the damage that often occurs, such as disputes over supervision of the shared land. The goodness of sulh is that the arguments will be solved voluntarily through an agreement and have legal recognition (Majallat al-Ahkam al-'Adliyyah, 1968).

There are verses of the Qur'an that recommend sulh to be applied, and among them are verse 128 of Surah al-Nisa', that Allah has said: It is not wrong for them (husband and wife) to make peace in between the two (in the best way), because peace is better (for them than divorce). In verse 9 of the Surah al-Hujurat, Allah also said: "And if two parties of the believers fight, then make peace between them". Therefore, the application of sulh among joint owners is a solution to overcome lengthy disputes among co-owners. However, the only sulh that is recognized is the one that complies with Islamic law. Therefore, any form of settlement or consensus that violates Islamic law is invalid and does not has legal recognition.

\section{Joint Ownership on the Family Company}

Establishing a family company also contributes to joint ownership when the setup is a partnership or occurs by inheritance. A family company or family business is a company that involves one, two, or more members of the same family who manage and control the finances of a business (Coulter, 2001; Scarborough, 2011). The family company is established by a family member and then taken over by heirs, such as wives, children, or relatives. As a result, family members become co-owners and responsible for making decisions based on their ownership and roles (Dean, 2005; Hashim et al., 2012). Or in other words, a company is owned, controlled, and operated by members of the same family in the form of co-sharers.

In the case of joint ownership, a family enterprise can result in joint ownership if an entrepreneur distributes shares to other family members through a gift or bequest (Lee, 2006; Asni \& Sulong, 2021). Therefore, the size of joint ownership among family members depends on its numbers and the property involves (Rosli, 2010). Each shareholder is a joint owner, and they share in the profits based on the portion of the shares they own. The function of a family company is like any other business that aims to make a profit and share it with the owners and employees. The uniqueness of a family company is that it will be inherited by family members and passed from one generation to another. Therefore, a family company is essential to the national economy and the income of family members (Kuratko, 2009). Successors who take over a family business need to understand the goals the company is founded on for the welfare of all heirs and must carry out management professionally.

Such property management is easier to accomplish because each joint owner can give an opinion familially, and after all, they are heirs. They can make innovations and rejuvenate the product to enrich the creation and enhance the profit. This includes family plantations or home-sites either diversify crops or make a house a rental or homestay. In this case, the success of family property is based on the bold initiative of the shareholders to develop it not only domestically but even abroad (Frederick and Kuratko, 2010). However, according to Alexis (2014), the only common problem faced by family companies is dissatisfaction among family members themselves. This is due to several factors such as management quality, future planning, profit distribution, age factors, lack of communication, envy, greed, and conservatism (Lee 2006; Yusof \& Yusof 2004). In short, the prosperity of the family company will last long if those negative attitudes can be eliminated professionally. 


\section{Shariah-Based Model Resolving Joint Ownership Issues}

When Islam recognizes joint ownership, Islam has underlined its guidelines as well. The guidelines can be traced and synthesized through its primary source, that is al-Qur'an and alHadith. Each owner has certain rights that need to be sustained and certain restrictions that cannot be violated. Therefore, this part will discuss the model-based under Shariah to resolve joint-ownership issues.

As joint ownership involves many owners, the first method is that they need to appoint a leader who can lead their ownership. The Prophet (pbuh) said: When three (Muslims) go out on a journey, then they should appoint one of them to be the leader" (Dawud, 1952). The head of this joint ownership can be referred to by various names such as mutawalli, administrator, trustee, nominee, or manager. The leader's prerequisite must be to be older, more respected, have a good personality, have a larger share, and be educated. This requirement will facilitate the management of a group of joint owners in a good manner, primarily to obtain understanding and agreement. Usually, the more respected and good personality will be more trustworthy in carrying out the duties. The Prophet (pbuh) very much emphasizes this attitude of trust when he states: "When trust is lost, then wait for the Hour." Abu Huraira said, "How is the trust lost, O Messenger of Allah?" The Prophet said, "When authority is given to those who do not deserve it, then wait for the Hour." " (Asqalani, 2001).

In achieving the first method, the second method appears that is in the shariah model, owners need to have discussions, consultations, or meetings between them. This type of engagement is inevitable in a partnership, where more than one co-sharer has a specific right, and they need a floor to fling their views. So the principle of having a meeting to deliberate matters collectively is a principle that must be implemented in Islam. The need is mentioned in the Koran which means, "... and consult them in the matter (wars and worldly matters), and when you have decided (after meeting, to do something) then rely upon Allah. Indeed, Allah loves those who rely [upon Him]" (Q3: 159). During the meeting, any issues and conditions will be resolved amicably. Each party needs to be open-minded to find a solution because as joint owners, all implications, whether bad or good, will be affected jointly.

Clearly, the shariah model for this kind of shared ownership is that by appointing a leader to manage all joint owners matters in harmony and peacefully. The appointment should be chosen from a trustworthy person and has an educational background so that the management will go smoothly. At the same time, the rights and welfare of each co-owner will be kept well. Then hold discussions with all owners to attain mutual good. At this final stage, the authorities can also intervene under the principles of Siyasah Syar'iyyah. Several legislations may be enacted to solemnize agreements between co-owners. Rules also can be set to ascertain their right from being abused by the appointed leader or my any elements of fraud.

\section{Conclusions}

The discussion found that joint ownership occurs in a few Islamic contracts, and it is permissible. Islam provides joint ownership through several transfer methods, namely inheritance, will, gift, and waqf. It can also happen through purchases and partnerships (sharikah) between family or friends. Each of the joint owners has certain rights and restrictions, depending on type of their sharing. In terms of rights, they are empowered to obtain benefits and profits based on their portion that was granted to them. While in terms of restrictions, some joint ownership has certain limits based on the rules and concepts of shared ownership. An important aspect of joint ownership is the spirit of cooperation and 
tolerance between the joint owners. This is because they own the property not solely but need to share it with others.

In joint ownership, its management is like religiously demanded towards a person in a group. They should appoint a leader or chief to lead the direction of the people, and the similar practise apply to jointly own property. The same viewpoint is also found on public property such as waqf where the Islamic law requires appointment of a property manager (mutawalli). His task is essential in ensuring every property's decision, planning, and management will be developed and realized successfully. Therefore, the joint ownership between family members, especially on family-owned waqf, farms, companies, or home-site such as those obtained from FELDA can be implemented well if a manager leads an agreement. This manager holds a trust for the welfare of the other heirs. Therefore, holding meetings and discussions between joint owners is essential.

As sum, to resolve the issue of joint ownership on agricultural land, Shariah law has underlined an excellent model to follow. The utmost vital step is to appoint a leader to manage the rest of joint owners who must be someone of trustworthy and educated. He has to conduct a meeting and deliberate things together to find solutions and ways to improve and sustain the productivity of the shared land. Under siyasah syar'iyyah, government can make an interjection in order to keep the rights of the parties in its place. These collaborations between individual, groups and authorities will ensure the welfare be kept tightened and the problems be resolved wisely.

\section{Acknowledgment}

Acknowledgment to Ministry of Higher Education Malaysia for Fundamental Research Grant Scheme with Project Code: FRGS/1/2020/SSIO/USM/02/1. 


\section{References}

Ahmad, M. Y., \& Ibrahim, I. A. (2006). Konsep harta menurut perspektif undang-undang Islam \& undang-undang sivil: Satu tinjauan. Jurnal Pengajian Umum, 7: 123-138.

Ahmad, M. Y., \& Laluddin, H. (2010). Pengurusan harta pusaka: Permasalahan sikap masyarakat Islam di Malaysia dan penyelesaiannya menurut perspektif Islam. Shariah Law Reports, 4: 30-54.

Ahmad, M. Y. (2017). Amalan muafakat dan aplikasi takharuj dalam pengagihan pusaka menurut perspektif undang-undang pusaka Islam. Islamiyyat: International Journal of Islamic Studies, 39 (1). 21-28.

Alexis, W. D. (2014). Pros \& cons of family business. Retrieved from HoustonChronicle.com: http://www.chron.com/ date retrieved: 20.7.2021

Asqalani, I. H. (2001). Fath al-Bari Syarh Sahih al-Bukhari. Beirut: Dar al-Fikr.

Awang, R. (1994). Undang-Undang Tanah Islam: Pendekatan Perbandingan. Kuala Lumpur: Dewan Bahasa dan Pustaka.

Aziz, B. (2009). "Takharruj Dalam Pembahagian Pusaka Islam : Kajian di Daerah Kota Setar". Tesis Sarjana Kejuruteraan. Universiti Teknologi Malaysia, Johor: Fakulti Kejuruteraan dan Sains Geoinformasi.

Aziz, U. A. (n.d.). Land Disintegration and Land Policy in Malaya. Kuala Lumpur : Universiti Malaya.

Buang, S. (2000). "Perils and Problems of Land Co-Ownership". In News Straits Times, 19 February 2000. Kuala Lumpur: The New Straits Times Press, p. 24.

Cohen, J. A. (1978). China's Changing Constitution. Harvard: Harvard Law School.

Coulter, M. K. (2001). Entrepreneurship in action. Upper Saddle River (N.J.): Prentice Hall.

Dawud, S. S. (1952). Sunan Abi Dawud. Mesir: Matba'at al-Babi al-Halabi.

Dean, C. F. (2005). An examination of the challenges daughters face in family business succession. Family Business Review, 18(4), 321-345.

Frederick, H. H., \& Kuratko, D. F. (2010). Entrepreneurship: Theory, process dan practice. Asia Pacific. Australia: Cengage Learning.

Hasari, A. (1992). al-Tarikat wa al-Wasaya wa al-Qadaya al-Muta'alliqat bihima fi al-Fiqh alIslami al-Muqaran. Beirut: Dar al-Jayl.

Hashim, N., \& Omar, S. (2007). Wakaf Jadi Aset Terbesar di bawah Portfolio MUIS. Berita Harian, p. 5.

Hashim, N., Deraman, N. \& Mohamad, A. (2012). Era Edar: Succession and conflicts. Management and Business. Sintok: Institute for Management and Business Research.

Ibn al-Humam, M. A. W. (n.d.). Sharh Fath al-Qadir 'ala al-Hidayah Sharh Bidayat al-Mubtadi li al-Marghinani. Beirut: Dar al-Fikr.

Ibn Manzur, J. M. M. (1990). Lisan al-'Arab. Beirut: Dar Sadir.

Isfahani, R. (1961). al-Mufradat fi Gharib al-Qur'an. Cairo: Matba'at Mustafa al-Babi alHalabi.

Jaburi, A. A., \& Hamish, A. H. (2007). Ahkam al-Mawarith wa al-Wasaya fi al-Shari'ah allslamiyyah. al-Shariqah: Jami'at al-Shariqah.

Jamalludin, N. (2016). Penyelesaian pusaka secara muafakat: Kajian di Unit Pembahagian Pusaka Selangor Barat Laut, Daerah Kuala Selangor. Latihan IImiah. Fakulti Pengajian Islam, Universiti Kebangsaan Malaysia.

Kahf, M. (2011). Waqf and its Sociopolitical Aspects. In Kahf. M \& Mahamood, S. M. (Eds.). Essential readings in contemporary waqf issues. Kuala Lumpur: CERT Publications, 399416. 
Karim, S. A. (2000). Contemporary Waqf Administration and Development in Singapore; Challenges and Prospect. Islamic Religious Council of Singapore, Singapore: n.p.p. 0-15.

Kasani, A. B. (1986). Bada'i al-Sana 'i fi Tartib al-Shara'i'. Beirut: Dar al-Kutub al-'Ilmiyyah.

Khalid, A. (2008). "Memudah Cara Pengurusan Tanah"” dalam Utusan Malaysia, 24 January 2008. Kuala Lumpur: Utusan Melayu Berhad, p. 14.

Kuratko, D. F. (2009). Introduction to entrepreneurship. Australia: South Western Cengage Learning.

Lee, J. (2006). Impact of family relationships on attitudes of the second generation in family business. Family Business Review, 176.

Mahamood, S. M. (2007), "Pembentukan Dana Wakaf Menurut Perspektif Syariah Dan Undang-Undang Serta Aplikasinya di Malaysia", Jurnal Syariah, 15(2), 61-83.

Mohamad, Z. (2007). Isu Pusaka Tanah Rancangan FELDA: Kajian Kes FELDA Lurah Bilut Bentong Pahang Darul Makmur. Prosiding Konvensyen Kebangsaan Pengurusan Harta Pusaka, Wasiat dan Wakaf. Bangi: Jabatan Syariah, Fakulti Pengajian Islam, Universiti Kebangsaan Malaysia.

Nawawi, M. (n.d.). al-Majmu'. Jeddah: Maktabah al-Irsyad.

Muhamad, N. H., \& Hussain, M. N. (2014). Pembahagian harta pusaka Felda: Perspektif masyarakat Islam Felda Taib Andak. Jurnal Teknologi. 66(1), 27-33.

Othman, B. (2009). "Cadangan Konsep dan Kaedah Pelaksanaan Pembangunan Kampong Bharu, Kuala Lumpur". Sesi Penerangan Kepada Pemilik dan Waris Tanah di Kampong Bharu, Kuala Lumpur anjuran bersama Kementerian Wilayah Persekutuan dan Kesejahteraan Bandar dan Dewan Bandaraya Kuala Lumpur.

Ramli, N., \& Ahmad, S. (2014). Sistem Pewarisan Tanah Felda (Gsa) Dan Kesannya Ke atas Hubungan Sosial Merentasi Generasi: Pendekatan Teori Dasar Sosial. The Asean Endowment Seminar 2014, 29 April 2014, Nilai, Negeri Sembilan.

Rashid, N. A. (1971). Land Law and Land Administration. K.L.: Universiti Malaya

Rosli, M. A. N. (2010). Prinsip-prinsip keusahawanan: Pendekatan gunaan. Singapore: Cengage Learning.

Saduman, S., \& Aysun, E. E. (2009). The Socio-Economic Role Of Waqf System In The MuslimOttoman Cities ' Formation And Evolution. Trakia Journal of Sciences, 7(2), 272-275.

Scarborough, N. M. (2011). Essentials of entrepreneurship and small business management. New York: Prentice Hall.

Shalabi, M. M. (1978). Ahkam al-Mawarith bayna al-Figh wa al-Qanun. Bayrut: Dar al-Nahdah al-'Arabiyyah.

Suhaimi, F. M. (2018). Wakaf Ahli: Peruntukan Undang-undang dan Perlaksanaannya di Malaysia. Malaysian Journal of Shariah and Law. 6(2), 73-81.

Sulong, J. (2019). Faraid A - Z. Kuala Lumpur: Dewan Bahasa dan Pustaka.

Asni, F., \& Sulong, J. (2021). "The mura'ah al-khilaf and ma'alat method in fatwa decisions: its application for fatwa coordination related to conditional hibah in Malaysia", International Journal of Islamic and Middle Eastern Finance and Management. https://doi.org/10.1108/IMEFM-05-2018-0181

Suman, M. S. (2012). Sepatutnya Begini: Himpunan Tulisan Berkaitan Dengan Urusan Perundangan dan Pentadbiran Tanah. Sepang : Koperasi Penolong Pegawai Selangor Berhad

Talib, A. A. (1997). Hadramis in Singapore. Journal of Muslim Minority Affairs, 17(1), 89-96. 
Ali, W. N. \& Ahmad, M. Y. (2013). Mekanisme aplikasi takharuj dalam pembahagian harta pusaka kecil di Kuala Terengganu. Islamiyyat: The International Journal of Islamic Studies, 35(2): 27-33.

Ali, W. N., \& Ahmad, M. Y. (2014). Konsep takharuj dalam hukum pusaka Islam. Jurnal Muamalat, 7, 117-132.

Wan Ali, W. N. (2016). Aplikasi prinsip al-takharuj dalam pembahagian harta pusaka kecil orang Islam di Terengganu. Tesis Sarjana. Jabatan Syariah, Fakulti Pengajian Islam, Universiti Kebangsaan Malaysia.

Harun, W. A. H. (2012). Isu-isu Pembahagian Harta Pusaka Orang Islam dalam Konteks Perundangan Malaysia. Kuala Lumpur: Dewan Bahasa dan Pustaka.

Yusof, A. Z., \& Yusof, Z. (2004). Prinsip keusahawanan. Sintok: Prentice Hall.

Zaki, I. (1995). Mujiz Ahkam al-Waqf. Kuwait: Kuwait Awqaf Public Foundation.

Zuhayli, W. (2015). al-Fiqh al-Islami wa Adillatuh, Beirut: Dar al-Fikr. 